\title{
PEMBELAJARAN ONLINE PADA MASA PANDEMI COVID 19 DI KELOMPOK BERMAIN (KB) MAWAR DESA SUMBERKOLAK SITUBONDO TAHUN 2020
}

Oleh:

\author{
Farida Sofiyanti, S.E ${ }^{1}$ \\ ${ }^{1}$ Ikatan Penilik Indonesia
}

Received: May 20, 2020

Revised: June 23, 2020

Accepted: June 25, 2020

\begin{abstract}
ABSTRAK
Pandemi covid 19 telah memberikan dampak yang luar biasa didunia pendidikan. Dengan adanya pandemi ini menjadikan masyarakat takut untuk melakukan kontak sosial secara langsung dengan orang lain sehingga pemerintah mengeluarkan kebijakan untuk lock down bahkan banyak sekolah yang diliburkan. PAUD mawar Sumberkolak sebagai salah satu lembaga pendidikan yang terdampak covid tetap berusaha melaksanakan pembelajaran ditengah pandemi covid 19 dengan menggunakan sistem daring atau online dengan menggunakan aplikasi WA. Banyak sekali permasalahan yang muncul dalam pelaksanaan pembelajaran online ini, baik itu permasalahan yang muncul dari guru, siswa dan wali siswa. Peneliti menggunakan metode penelitian kualitatif untuk menganalisis data penelitian terkait pembelajaran online yang dilaksanakan di PAUD Mawar Sumberkolak, Situbondo. Kesimpulan dari penelitian ini adalah PAUD Mawar Sumberkolak tetap berusaha melaksanakan pembelajaran walaupun masih berjalan dengan maksimal karena masih banyak problematika yang muncul dalam pelaksanaan pembelajaran tersebut. Salah satu solusi yang dapat ditawarkan adalah perlu adanya sosialisasi dan pembimbingan terhadap wali siswa dalam melaksanakan pembelajaran online.
\end{abstract}

Kata Kunci: PAUD Mawar, Pembelajaran Online

\section{ABSTRACT}

Covid pandemic 19 has had a tremendous impact on the world of education. With this pandemic making people afraid to make direct social contact with others, the government issued a policy to lock down even many schools were closed. PAUD rosal Sumberkolak as one of the educational institutions affected by covid still strives to carry out learning in the midst of the covid pandemic 19 by using an online or online system using the WA application. Lots of problems that arise in the implementation of online learning, both problems that arise from teachers, students and student guardians. Researchers used qualitative research methods to analyze research data related to online learning conducted at Mawar Sumberkolak PAUD, Situbondo. The conclusion of this research is PAUD Mawar Sumberkolak still trying to carry out learning even though it is still running 
optimally because there are still many problems that arise in the implementation of the learning. One solution that can be offered is the need for socialization and guidance of student guardians in carrying out online learning.

Keyword: PAUD Mawar, Online Learning

\section{Pendahuluan}

Pandemi covid 19 ini membuat jarak individu satu dengan yang lain, bahkan pembelajaran disekolahpun dihentikan dan diganti dengan pembelajaran online dari rumah masing-masing. Kondisi seperti ini memunculkan kekhawatiran terhadap keberlangsungan pembelajaran siswa yang pastinya masih sangat membutuhkan bimbingan dan pendampingan dalam pembelajaran. Pembelajaran online ditawarkan sebagai solusi menghadapi permasalahan tersebut, walaupun sebenarnya kesiapan siswa masih sangat problematik dalam meghadapi pembelajaran secara daring.

Proses belajar daring ini tentunya diharapkan dapat menjauhkan anak dari kemungkinan terpapar virus Corona. Proses belajar daring ini tak hanya diterapkan oleh sekolah dasar, atau pun sekolah menengah saja, melainkan juga bagi tingkat pendidikan anak usia dini (PAUD). Salah satunya yaitu PAUD Mawar yang terletak di Situbondo. Sekolah yang didesain khusus untuk anak-anak usia dini ini tetap menjalankan proses belajarnya secara online menggunakan aplikasi whatshapp

Bermain Aktif, Belajar Kreatif Meskipun belajar secara daring, guru-guru di PAUD Mawar tetap mendorong murid-murid bermain secara aktif bersama orang tua, dan belajar menjadi individu yang kreatif. Hal itu terlihat dengan pembuatan program belajar yang menarik di setiap harinya, seperti belajar berhitung dengan engklek, bermain playdough, melakukan conference call, membuat boneka tangan dengan kaos kaki yang sudah tak terpakai, dan lain sebagainya. Bu erna, salah satu pendidik di PAUD Mawar Sumberkolak, menceritakan pengembangan program belajar bersama orang tua di rumah dengan membuat boneka tangan. "Dalam proses belajar daring di kelas untuk program aku sebagai warga dunia, anak-anak diberikan kegiatan berupa bermain boneka tangan menggunakan kaos kaki

Proses belajar PAUD Mawar secara daring turut mendorong antusiasme orang tua untuk mendampingi anak-anaknya dan juga belajar bersama. Kegiatan bekerja dari rumah juga menjadi salah satu alasan keikutsertaan orang tua untuk turut belajar bersama anak-anak. Rendra Purnama memaparkan bahwa orang tua turut berpartisipasi aktif dalam proses belajar online anak-anak mereka, bahkan mengapresiasi pembuatan konten belajar yang kreatif dari 
guru-guru di PAUD Mawar. "Sejauh ini, beberapa orangtua yang menyampaikan langsung antusiasmenya dengan mengirimkan video saat anak-anak mereka berpartisipasi dalam mengikuti kegiatan belajar online. Orangtua menanggapinya dengan positif, bahkan tidak segan untuk memuji guru yang sangat berperan dalam perkembangan anak-anak mereka," ucapnya.

Proses belajar bagi anak usia dini secara online di rumah saat Covid-19 ini menjadi sebuah langkah yang tepat untuk pengembangan proses belajar digital di tingkat pra-sekolah. "Dalam kondisi seperti ini, pembelajaran online bagi anak usia dini dirasa tepat sekali bagi PAUD Mawar Sumberkolak. PAUD Mawar selalu berupaya untuk tetap mempertahankan hak murid sebagai subyek pendidikan agar tetap belajar dalam kondisi apapun. Melalui dukungan teknologi, proses belajar di PAUD Mawar tetap berupaya menyediakan program belajar bagi murid-murid dengan konten/ isi yang senantiasa berkualitas.

\section{Metode Penelitian}

\section{Pendekatan dan Jenis Penelitian}

Sebelum penulis melakukan penelitian, penulis akan memberikan gambaran mengenai desain penelitian. Desain penelitian adalah semua proses yang diperlukan dalam perencanaan dan juga dalam pelaksanaan penelitian. Pada penelitian ini, penulis menggunakan penelitian kualitatif, yaitu suatu proses menemukan pengetahuan yang menggunakan data berupa angka sebagai alat untuk menemukan keterangan mengenai apa yang ingin kita ketahui. Penelitian kualitatif ini berupa penelitian secara deskriptif analisis. (Margono, 2004:45-46).

Setting penelitian yang akan dilakukan adalah penelitian kualitatif juga bisa dimaksudkan sebagai jenis penelitian yang temuan-temuannya tidak diperoleh melalui prosedur statistik atau bentuk hitungan lainnya (Strauss \& Corbin, 2003). Sekalipun demikian, data yang dikumpulkan dari penelitian kualitatif memungkinkan untuk dianalisis melalui suatu penghitungan.

Dalam penelitian ini menggunakan pendekatan kualitatif yaitu bertujuan menghasilkan kesimpulan penelitian di lapangan. penelitian kualitatif adalah penelitian yang memfokuskan pada kegiatan-kegiatan mengidentifikasi, mendokumentasi, dan mengetahui dengan interpretasi secara mendalam gejala-gejala nilai, makna, keyakinan, dan karakteristik umum seseorang atau kelompok masyarakat tentang peristiwa-peristiwa kehidupan. (Usman, 2001:74). 
Sesuai dengan pokok permasalahan dan tujuan yang ingin dicapai dalam penelitian, maka penulis akan membuktikan apa yang menjadi kesimpulan, untuk dipadukan dengan data yang ada sehingga akan tercapai suatu kebenaran.

Penelitian ini mengunakan jenis penelitian yang kedua, yaitu Penelitian terapan agar hasilnya segera dapat dipahami untuk keperluan praktis, dan untuk pembelajaran online di PAUD Mawar Sumberkolak Situbondo.

\subsection{Kehadiran Peneliti}

Kehadiran peneliti kualitatif sangat penting karena hal ini sesuai dengan pendapat Nur Hamim dan kawan-kawan (2011:25), dalam penelitian ini perlu disebutkan bahwa peneliti bertindak sebagai insetrumen sekaligus pengumpul data. Insetrumen selain manusia dapat pula digunakan, tetapi fungsinya terbatas sebagai pendukung tugas peneliti sebagai instrumen. Oleh kerna itu, kehadiran peneliti di lapangan untuk penelitian kualitatif mutlak diperlukan. Disamping itu juga seorang guru di PAUD Mawar Sumberkolak Situbondo.

Instrumen penelitian merupakan alat bantu bagi peneliti dalam mengumpulkan data, kualitas insetrumen akan menentukan kualitas data terkumpul, oleh kerena itulah, menyusun insetrumen bagi kegiatan penelitian merupakan langkah penting yang harus dipahami betul oleh peneliti

\subsection{Lokasi Penelitian}

Penentuan tempat penelitian ini menggunakan pemilihan tempat penelitian dilakukan dengan sengaja dan ditentukan sendiri oleh peneliti karena peneliti mengenal tempat tersebut. Tempat penelitian ditetapkan di PAUD Mawar Sumberkolak Situbondo. Alasan peneliti memilih tempat penelitian di PAUD Mawar Sumberkolak Situbondo karena peneliti ingin mengetahui pembelajaran online di PAUD Mawar Sumberkolak Situbondo.

\subsection{Data dan Sumber Data}

Sumber data dalam penelitian ini diproleh oleh peneliti dari key informan, Yaitu orang yang dapat memberikan informasi kepada peneliti, seperti kepala sekolah, guru, staf dan siswa serta data yang berkaitan dengan penelitian, baik itu data primer atau data sekunder.

Arikunto (2006:293) berpendapat bahwa sumber data adalah subyek penelitian di mana data menempel. Sumber data dapat berupa benda, gerak, manusia, tempat dan sebagainya. Sumber data diperoleh dari tiga metode yaitu metode wawancara, metode observasi dengan mengobservasi pembelajaran online di PAUD Mawar Sumberkolak Situbondo.

\subsection{Prosedur Pengumpulan Data}


Dalam pengumpulan data diperlukan adanya teknik yang tepat dan sesuai dengan data yang akan diperoleh, sehingga dapat terhindar dari kesalahan dalam meperoleh data tersebut. Beberapa teknik pengumpulan data yang terdiri dari; a). Observasi; b). Interview; dan c). Dokumentasi.

\subsubsection{Observasi}

Observasi adalah merupakan metode pengumpulan data yang menggunakan pengamatan terhadap obyek penelitian melalui metode observasi seorang peneliti dapat mengamati gejala-gejala yang terjadi di lapangan. Sutrisno Hadi, (2009:12) memaparkan bahwa observasi biasanya diartikan sebagai pengamatan dan pencatatan dengan sistematik fenomena-fenomena yang diselidiki. Hal ini sesuai dengan pendapat Cholid Narbuko yang mengemukakan bahwa "pengamatan adalah alat pengumpulan data yang dilakukan cara mengamati secara sistematik gejala-gejala yang diselidiki"(2003:70).

Berdasarkan pendapat diatas dapat disimpulkan bahwa yang dimaksudkan dengan observasi adalah melakukan pengamatan dan pencatatan secara sistematis terhadap suatu obyek dengan menggunakan suatu indera (terutama mata) terhadap kejadian-kejadian yang diselidiki. Observasi dilakukan dengan tujuan untuk mengetahui kondisi pada saat proses pembelajaran.

Menurut (Yatim Riyanto, 2001:98-99), jenis penelitian dibedakan menjadi 5 yaitu:

a. Observasi partisipan adalah Observasi dimana orang yang melakukan pengamatan berperan serta ikut ambil bagian dalam kehidupan orang yang di Observasi.

b. Observasi Non Partisipan dikatakan non partisipan apabila Observer tidak berperan serta ikut ambil kehidupan Observer.

c. Sistematik (Structured observation), Observasi sistematik apabila pengamatan menggunakan pedoman sebagai instrumen pengamatan

d. Observasi non sistematik Observasi yang dilakukan oleh pengamat dengan tidak menggunakan instrumen pengamatan.

e. Observasi Eksperimental pengamatan ini dilakukan dengan cara Observer dimaksudkan kedalam suatu kondisi atau situasi tertentu

Dari beberapa jenis Observasi yang telah disebut diatas. Maka Observasi yang penulis gunakan dalam penelitian ini adalah Observasi partisipan dan dilengkapi dengan Observasi sistematik, artinya didalam mengadakan Observasi. Penelitian langsung turut aktif ngadakan pengamatan dengan mengadakan pendekatan kepada siswa dengan menggunakan kerangka terlebih dahulu yang berisi faktor-faktor yang telah diatur 
berdasarkan kategori masalah yang hendak di Observasi secara bebas dibatasi oleh halhal lain membatasi jalanya Observasi.

Adapun data yang ingin diraih diperoleh dengan menggunakan metode ini adalah tentang :

1. Keadaan atau kondisi sekolah di PAUD Mawar Sumberkolak Situbondo.

2. Sarana dan Prasarana di daerah penelitian.

3. Kegiatan kurikuler yang meliputi aktivitas belajar siswa dan kegiatan ekstrakurikuler.

\subsubsection{Interview}

Interview adalah sebagai suatu proses tanya jawab lisan, dalam mana dua orang atau lebih berhadap-hadapan secara fisik, yang satu dapat melihat muka yang lain dan mendengarkan dengan telinga sendiri sendiri. (Hadi, 2003:63) Menurut (Yatim Riyanto, 2001:96).

Dari pernyataan di atas, maka dapat diambil pengertian bahwa interview adalah suatu teknik memperoleh data dengan jalan mengadakan tanya jawab dengan wawancara secara langsung dengan maksud untuk mendapat keterangan yang lebih jelas, cepat dan menimbulkan hubungan yang akrab. Peneliti akan mewawancara kepala sekolah guru, serta siswa.

Teknik ini digunakan untuk mendapatkan data informasi tentang pembelajaran online di PAUD Mawar Sumberkolak Situbondo, baik yang berkenaan dengan guru, siswa, buku ajar, media, metode dan lain sebagainya.

\subsubsection{Dokumentasi}

Teknik dokumentasi merupakan teknik untuk data yang berhubungan dengan hal-hal atau variabel yang berupa catatan, transkrip, buku, surat kabar, majalah, prasasti, notulen rapat, legger, agenda dan sebagainya. Teknik dokumentasi ini, penulis gunakan untuk menggali data tentang struktur organisasi sekolah, denah atau peta sekolah, keadaan guru dan siswa serta data-data lain yang terkait dengan masalah penelitian.

\subsection{Analisis Data}

Suatu penelitian belum sempurna dan belum dapat dipertanggung jawabkan bila tidak disertai dengan analisis data. Analisis data merupakan suatu langkah yang sangat menentukan dalam sebuah penelitian. Data yang telah terkumpul kemudian dipilih, didata, dan disusun sesuai dengan permasalahan yang diteliti yang kemudian disajikan dalam tabel-tabel.

Dalam hal ini penulis menggunakan metode sebagai berikut: 


\subsubsection{Induksi}

Metode ini merupakan suatu cara berfikir dari fakta yang bersifat khusus yang kemudian ditarik suatu kesimpulan yang bersifat umum.

Dalam metode induksi ingin mengungkapkan pembuktian kebenaran pembelajaran online yang dilakukan oleh siswa yang didampingi orang dewasa dengan berlandaskan pengetahuan-pengetahuan yang khusus dan faktor-faktor yang ada dan merangkaikan faktorfaktor khusus itu menjadi suatu pemecahan yang bersifat umum.

\subsubsection{Reduksi Data}

Analisis data yang digunakan dalam penelitian ini adalah analisis deskriptif kualitatif, yaitu memaparkan data yang diperoleh dari hasil pelaksanaan tindakan yang mencakup proses dan dampak yang terjadi dalam penelitian secara keseluruhan dan dalam analisis data dilakukan dengan tiga tahap, yaitu:

1. Reduksi data, reduksi data adalah proses penyederhanaan yang dilakukan melalui Seleksi, pemfokusan, pengabstraksian data mentah menjadi informasi yang bermakna; pada kegiatan reduksi akan menjelaskan tentang pembelajaran online yang dilaksanakan selama pandemi covid19..

2. Paparan data, paparan data adalah proses penampilan data secara lebih sederhana dalam bentuk paparan naratif, representasi grafis dan sebagainya;

3. Penyimpulan, penyimpulan adalah proses pengambilan intisari dari sajian data yang lebih terorganisasikan bentuk pernyataan kalimat dan/atau formula singkat dan padat tetapi mengandung pengertian luas. (Moleong, 2003:95).

Analisis data adalah proses Pengorganisasian dan pengurutan data ke dalam pola, kategori dan satuan uraian dasar, sehingga dapat, ditemukan tema seperti yang disarankan oleh data" Teknik analisis data yang digunakan dalam penelitian ini adalah analisis deskriptif. Penelitian deskriptif dirancang untuk memperoleh informasi tentang status gejala pada saat penelitian dilakukan. Dengan cara diorganisir, kemudian dikerjakan yang akhirnya data tersebut diungkap permasalahan yang penting sesuai dengan topik yang sesuai dengan permasalahan. Selanjutnya Miles \& Hubermen menerapkan tiga alur kegiatan dalam analisis deskriptif yang menjadi satu kesatuan tak dapat terpisahkan yaitu:

Gambar 1 Komponen-komponen Analisis Data: Model Interaktif

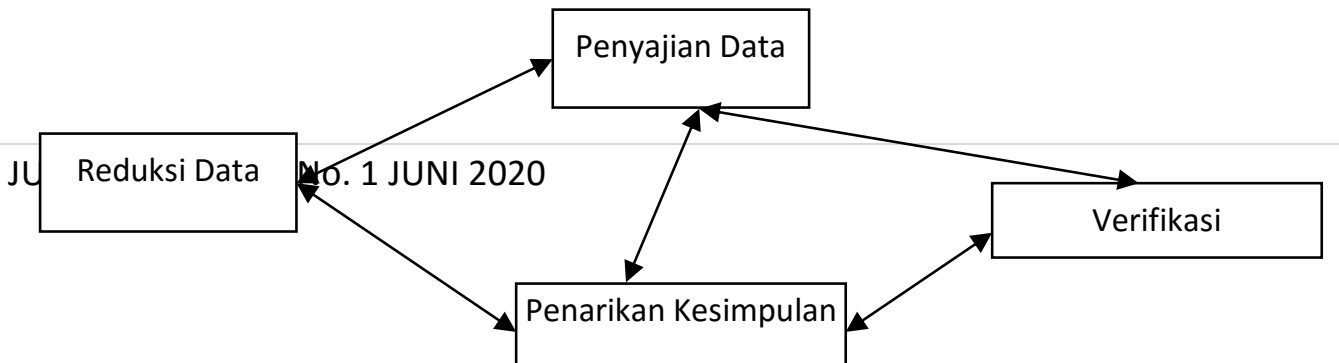


(1) reduksi data, (2) penyajian data, dan (3) penarikan Kesimpulan atau verifikasi.

Reduksi data, pada teknik ini peneliti melakukan proses penilaian pemusatan perhatian untuk penyederhanaan, pengabstrakan, dan transformasi data mentah atau data kasar yang muncul dari catatan-catatan di lapangan.

Laporan lapangan sebagai bahan mentah direduksi, diringkas, ditonjolkan pokokpokoknya dan disusun lebih sistematis, sehingga lebih mudah dikendalikan. Data yang direduksi dapat memberikan gambaran yang lebih jelas tentang hasil pengamatan, juga memberikan kemudahan bagi peneliti dalam mendapatkan kembali data yang diperoleh jika diperlukan.

Penyajian data, teknik ini memaparkan hasil temuan secara narasi.

Penyajian kesimpulan, teknik ini peneliti berusaha agar dapat menggambarkan kerepresentatifan suatu peristiwa, kejadian atau subjek.

\subsection{Pengecekan Keabsahan Penelitian}

Langkah akhir penulis lakukan dalam penyusunan karya ilmiah ini adalah mengadakan pengabsahan data dan penafsiran data, mengolah hasil sementara menjadi teori subtansif yang disusun dalam pernyataan argumentative.

Keabsahan data penulis lakukan untuk memperoleh temuan interpretasi yang absah, dengan mengunakan empat teknik pemeriksaan, yaitu:

1. Perpanjangan keikutsertaan (Paul Rock menyatakan bahwa teknik perpanjangan keikutsertaan mungkin sangat penting dalam interaksi simbolik yang memungkinkan peneliti menggunakan “diri”(Self)nya untuk menjelajahi proses sosial). Perpanjangan pengamatan berarti peneliti kembali ke lapangan melakukan pengamatan, observasi ulang dengan sumber data yang telah diperoleh. Peneliti merasa perlu menggunakan perpanjangan pengamatan sebab dalam mengetahui pembelajaran online di PAUD Mawar Sumberkolak Situbondo siswa perlu diadakan beberapa kali tindakan, sehingga dapat mengetahui secara cermat tata-cara pembelajaran online. Selain itu juga untuk menambah keakraban kepada sumber data seperti kepala sekolah, dan guru sebagai sumber data yang memberikan informasi terhadap penelitian yang dilakukan. 
2. Ketekunan pengamatan (Ketekunan pengamatan bermaksud untuk menemukan ciri-ciri dan unsur-unsur dalam situasi yang sangat relevan dengan persoalan atau isu yang sedang dicari dan kemudian memutuskan diri pada hal-hal tersebut secara rinci). Meningkatkan ketekunan berarti melakukan pengamatan secara jelas dan cermat serta berkesinambungan. Dengan cara ini maka kepastian data akan diperoleh dengan baik. Untuk meningkatkan ketekunan guna terlaksananya penelitian ini dan untuk membantu peneliti mempermudah memperoleh data yang dibutuhkan, maka peneliti dapat membaca beberapa referensi guna memperoleh informasi guna mendapat data-data yang dibutuhkan dalam penelitian.

3. Triangulasi (Triangulasi adalah teknik pemeriksaan keabsahan data yang memanfaatkan sesuatu yang lain diluar data itu untuk keperluan pengecekan atau sebagai pembanding terhadap data itu). Triangulasi dalam pengujian kredibilitas ini diartikan sebagai pengecekan data dari berbagai sumber dengan cara dan waktu. Peneliti menggunakan tehnik triangulasi sumber untuk menguji kredibilitas data dilakukan dengan cara mengecek data yang telah diperoleh melalui beberapa sumber. Hal ini dimaksudkan agar data-data atau informasi yang berasal dari sumber dapat membantu proses penelitian agar terjamin keabsahannya sehingga penemuan dalam penelitian tersebut memperoleh kepercayaan. Triangulasi sumber dalam penelitian ini.

4. Pemeriksaan sejawat melalui diskusi (Agar peneliti tetap mempertahankan sikap jujur, terbuka dan diskusi dengan teman sejawat ini memberikan suatu kesempatan awal yang baik untuk memulai penjajakan dan menguji hipotesis kerja yang muncul dari pemikiran peneliti). Tujuan pemeriksaan sejawat melalui diskusi adalah untuk mengetahui seberapa jauh data yang diperoleh, sesuai dengan apa yang diberi dan oleh pemberi data. Peneliti mengadakan pemeriksaan sejawat melalui diskusi ini digunakan sebagai alat cross check sehingga informasi yang didapat dari pemberi data atau pemberi informasi dapat dipadukan kebenarannya dengan temuan baru dalam penelitian.

5. Proses analisis data dimulai dengan menelaah seluruh data yang tersedia dari berbagai sumber, kemudian mereduksi dengan cara membuat abstraksi, berisi beberapa rangkuman pokok, proses dan beberapa peryataan informan. Tahapan akhir dari analisis data ini adalah mengadakan pemeriksaan keabsahan data.

\section{PEMBAHASAN}

Berdasarkan hasil wawancara bersama pengelola PAUD Mawar sumberkolak Situbondo menyatakan bahwa selama terjadi wabah covid 19 ini pembelajaran di PAUD 
Mawar Sumberkolak dil;aksanakan dari rumah masing-masing dengan menggunakan pembelajaran jarak jauh dengan aplikasi WA. Kepala sekolah meminta kepada pendidik PAUD untuk membuat perencanaan pembelajaran yang untuk kemudian dishare kepada siswa melalui WA grup wali siswa. Begitupun dengan pemberian tugas pembelajaran kepada siswa juga disharemelalui WA dan untuk kemudian hasil dari tugas siswa dikumpulkan kepada pendidik melalui WA yang bisa berupa foto ataupun video hasil mengerjakan tugas. Pelaksanaan pembelajaran ini dilakukan dirumah masing-masing dengan alasan untuk meminimalisisr penularan virus corona yang memang saat ini masih mewabah di seluruh penjuru dunia.

Pembelajaran dengan menggunakan sistem DARING ataupun sistem online ini masih mengalami banyak problematika dalam penerapannya, karena anak tidak dapat belajar sendiri tanpa pendampingan dari orang dewasa yang paham cara mengoperasionalkan android. Ketersediann paket data juga menjadi hal yang perlu diperhitungkan dalam menerapkan pembelajaran dengan menggunakan aplikasi WA karena tanpa paket data maka pembelajaran yang menggunakan aplikasi WA ini tidak akan terlaksana. Letak geografis suatu daerah juga mempengaruhi kelancaran dari pembelajaran dengan menggunakan aplikasi WA karena apabila daerah siswa berada di daerah yang tidak terjangkau sinyal maka akan membuat komunikasi pembelajaran menjadi terputus-putus. Yang tidak kalah penting adalah keberadaan sarana yang dimiliki untuk melaksanakan pembelajaran dengan menggunakan aplikasi WA yaitu android itu sendiri, masih banyak masyarakat yang belum mengenal dan memiliki teknologi komunikasi yang berupa android. Tanpa android maka pembelajaran dengan menggunakan aplikasi WA ini tidak akan terlaksana sama sekali.

Berdasarkan keterangan yang disampaikan oleh pendidik PAUD Mawar Sumberkolak menyatakan bahwa pembelajaran online dilaksanakan setiap hari senin sampai jumat dengan menggunakan aplikasi WA. Banyak permasalahan yang muncul dalam pembelajaran online yang menggunakan aplikasi WA, yang diantaranya adalah tidak semua walimurid paham tentang IT dan tidak semua walimurid memiliki android.

Pendidik PAUD Mawar juga menjelaskan bahwa respon anak dalam pembelajaran online ini banyak yang merasa senang karena menggunakan HP yang bisa juga digunakan untuk bermain, namun disisi lain juga banyak siswa yang mempertanyakan kapan bisa sekolah lagi bersama bu guru, kapan bisa menyanyi bersama, kapan bisa bermain bersama bu guru dan teman-teman. Pertanyaan ini sebenarnya mengungkapkan ada yang kurang dalam sistem pembelajaran online dengan menggunakan WA. Anak usia PAUD membutuhkan 
bersosialisasi secara langsung dalam pembelajaran untuk mendapatkan pengalaman belajar yang lebih nyata.

Dalam keterangan yang lain juga pendidik PAUD Mawar ini juga menyatakan bahwa pembelajaran dilaksanakan dengan menggunakan metode pembelajaran simulasi, ceramah dan tutorial. Metode pembelajaran ini dipilih karena memang dianggap sebagai metode yang mudah diaplikasikan dalam pembelajaran online menggunakan WA. Sedangkan terkait penugasan, guru memberikan tugas berupa praktek dan tugas LKS.

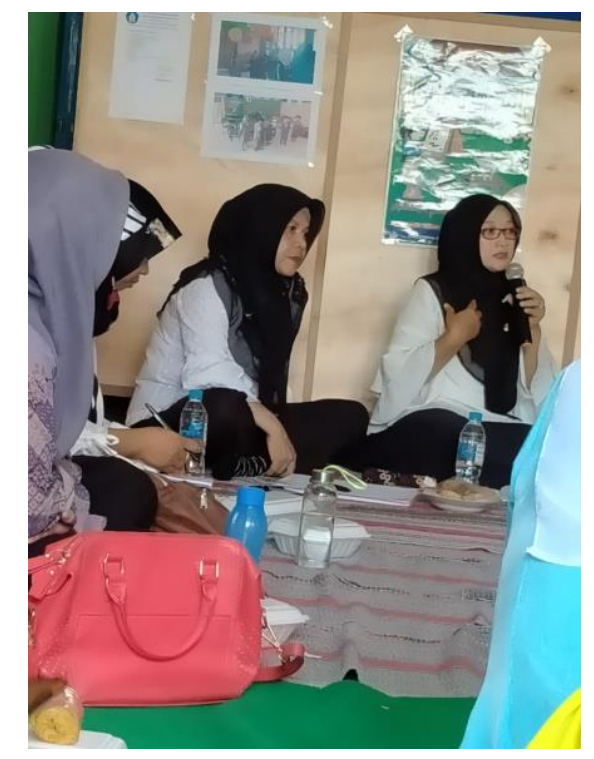

Proses evaluasi pembelajaran dilakukan guru dengan cara mengevaluasi hasil belajar siswa yang dilaporkan oleh wali siswa melalui WA, baik itu berupa foto maupun video. Untuk kemudian guru memberikan nilai terhadap hasil belajar siswa dengan menggunakan deskripsi hasil belajar.

Proses evaluasi yang dilakukan dengan mewajibkan siswa untuk mengirim hasil pekerjaan belajarnya melalui WA ini terkadang masih diragugan kesahihannya karena

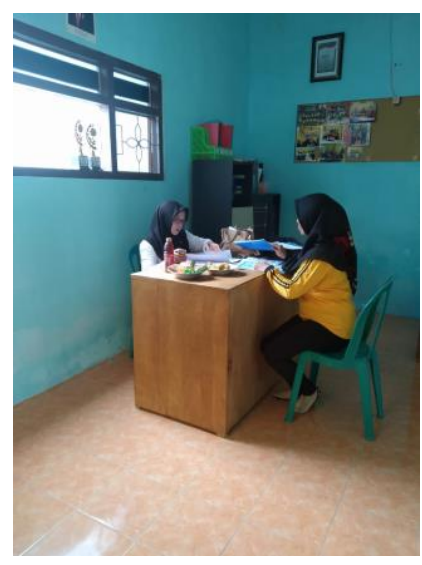


terkadang anak melakukan pekerjaan belajarnya lebih banyak dibantu oleh orang tuanya, hal ini akan memberikan efek kurang baik kepada anak didik karena dia akan benyak tergantung kepada orang tuanya.

Hasil wawancara dengan wali murid menyatakan bahwa pembelajaran online kurang menarik untuk anak-anak-anak karena anak usia dini masih berada pada dunia bermain dan bersosialisasi dengan teman-temannya. Kenyataan ini memang tidak dapat dipungkiri bagi anak usia PAUD mereka butuh belajar bersama guru dan teman-temannya di sekolah untuk mendapatkan pengalaman belajar yang nyata.

Dari informasi yang didapatkan dari walimurid menyatakan bahwa banyak sekali masalah-masalah yang muncul dalam pelaksanaan pembelajaran online yang didampingi oleh orangtua, yang diantaranya adalah, anak kurang percaya terhadap kemampuan orang tuanya dalam mendampingi belajar, karena anak lebih percaya kepada gurunya. Masih banyak wali murid yang belum paham IT sehingga kesulitan mengikuti pembelajaran online. Banyak orang tua yang kesulitan membagi waktu antara membimbing anak dan menyelesaikan pekerjaan, dan permasalahan yang terakhir adalah kesulitan dalam memberikan bimbingan kepada anak karena memang tidak semua orang tua memiliki basic pendidikan yang memadai.

Problematika ini membutuhkan solusi yang mapan agar pembelajaran online yang diterima anak PAUD berjalan dengan efektif dan efisien. Ketika pembelajaran berjalan efektif dan efisien maka akan memberikan dampak positif terhadap perkembangan anak baik aspek kognitif, afektif dan psikomotorik.

Dari beberapa permasalahan yang ditemukan dalam penelitian dapat ditawarkan solusi pembelajaran online agar berjalan dengan baik adalah harus mengadakan sosialisasi kepada walimurid terkait pelaksanaan pembelajaran online. Dengan adanya sosialisasi ini diharapkan akan memberikan sedikit pencerahan kepada walimurid dalam mendampingi pembelajaran anak-anaknya.

\section{KESIMPULAN}

PAUD Mawar Sumberkolak tetap melaksanakan pembelajaran dimasa pandemi covid 19 dengan menggunakan aplikasi WA. Walaupuntidak berjalan secara maksimal namun tetap ada usaha yang dilakukan oleh pihak lembaga untuk memberikan layanan pendidikan sebagai bukti kesungguhan dalam mendidik siswa dan siswinya. 


\section{DAFTAR PUSTAKA}

Margono, 2004, Metodologi Penelitian Pendidikan, Jakarta :Rineka Cipta.

Anselm, Strauss dan Juliet Corbin. (2003). "Dasar-dasar Penelitian Kualitatif”. Yogyakarta :

Pustaka Belajar.

Usman. 2001. Metodologi penelitian sosial. Jakarta: Bumi Aksara

Darmadi, Hamid. 2011. Metode Penelitian Pendidikan. Bandung: Alfabeta.

Arikunto, S. 2006. Metode Penelitian Kualitatif. Jakarta: Bumi Aksara

Hadi, Sutrisno. 2009. Metodologi Research. Yogyakarta : Yayasan Pendidikan Fakultas Psikologi Unversitas Gajahmada.

Narbuko, Cholid. 2003. Metodologi Penelitian. Jakarta: Bumi Aksara

Riyanto, Yatim. 2001. Metodologi Penelitian Pendidikan. Surabaya: Penerbit SIC.

Moleong. 2003. Metodologi Penelitian Kualitatif. Bandung: Remaja Rosdakarya 